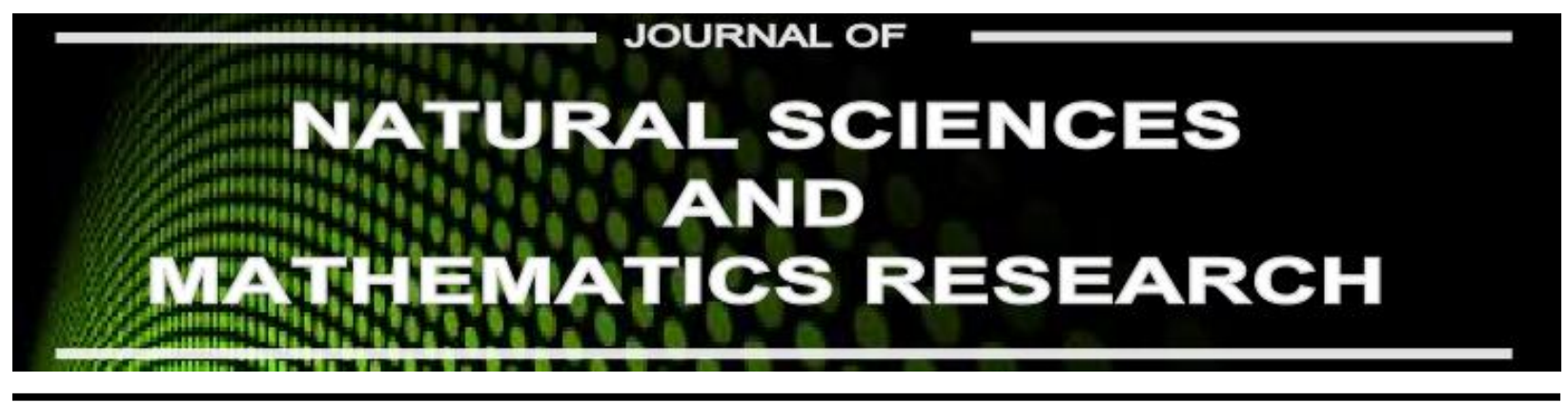

Available online at http://journal.walisongo.ac.id/index.php/jnsmr

\title{
Preparation and Microstructure of Ag Doped on ZnO
}

\section{Sheilla Rully Anggita ${ }^{1}$, and Heri Sutanto ${ }^{2}$}

${ }_{1}^{1}$ Department of Physic Education, Faculty of Science and Technology UIN Walisongo, Indonesia

2 Department of Physic, Faculty of Science and Matematika, Diponegoro University, Indonesia

\begin{abstract}
s
Corresponding author: Various concentration of silver (Ag) dopant on $\mathrm{ZnO}$ (ZnO:Ag) 2-8 mol\% with solsheilla1126@gmail.com Recived: 06 November 2016, Revised : 10 December 2016 Accepted: 27 December 2016. gel method were deposited on glass substrates that has been heated to a temperature of $250^{\circ} \mathrm{C}$ for $1 \mathrm{~h}$ using a thermal spray coating technique and then annealed on $400^{\circ} \mathrm{C}$ for $1 \mathrm{~h}$. The obtained samples were characterized by Scanning Electron Microscopy (SEM). The effect of various Ag dopant on ZnO on the microstructure are investigated. The results showed that the microstructure of $\mathrm{ZnO}: \mathrm{Ag}$ are the surface of $\mathrm{ZnO}$ make ganglia phase with $\mathrm{Ag}$ grains covered the surface. The addition concentration of Ag promotes the growth of ganglia phase and grain size. The surface of $\mathrm{ZnO}: \mathrm{Ag} \leq 4 \mathrm{~mol} \%$ the growth grain $\mathrm{Ag}$ is more dominant than the growth of $\mathrm{ZnO}$. The dopant Ag with a concentration of 4$8 \mathrm{~mol} \%$ ganglia structure begin to form with the presence of grains. Obtained the surface of $\mathrm{ZnO}: \mathrm{Ag} 4 \mathrm{~mol} \%$ begins to growth ganglia phase with the largest grain diameter is $304.8 \mathrm{~nm}$. (C2016 JNSMR UIN Walisongo. All rights reserved.
\end{abstract}

Keywords: Thermal Spray; Coating; ZnO; Ag dopant; Microstructure

\section{Introduction}

Zinc Oxide $(\mathrm{ZnO})$ is one of semiconductor that acts as a photocatalyst. The photocatalytic activity of $\mathrm{ZnO}$ has been explored and reported. $\mathrm{ZnO}$ has the ability to degrade pollutants more effective, economic, and environmentfriendly[1]. $\mathrm{ZnO}$ is used as a photocatalyst material due to low corrosion, relatively easy synthesis, and has a high photocatalytic activity[2][3]. Several studies with several methods have been performed to enhance the photocatalytic activity of $\mathrm{ZnO}$. ZnO doped with various transition metal dopants has been investigated. By increasing the concentration of doped transition metal, the energy level is changed which is able to improve the physical and optical properties [4]. In previous research utilizing silver $(\mathrm{Ag})$ doped on $\mathrm{ZnO}$ ( $\mathrm{ZnO}: \mathrm{Ag}$ ) is able to increase photocatalytic activity [3][4].

$\mathrm{Ag}$ doped $\mathrm{ZnO}$ with various deposition methods such as thermal decomposition, coprecipitation, sol-gel and others that have been performed by previous researchers 
produced various microstructures. Some of them are microrods [3], nanocrystalline [4][5][6], nanorods [7], grains [8] and ganglialike phase structure [9]. Ag doped $\mathrm{ZnO}$ microstructure photocatalyst with high activity has been intensively researched [1-9]. Meanwhile, the higher surface area is also an important factor for enhancement of photocatalytic perfomance of $\mathrm{Ag}$ doped $\mathrm{ZnO}$ catalyst [1]. Ganglia phase structure $\mathrm{ZnO}: \mathrm{Ag}$ were found that Ag grain were agglutinated to the $\mathrm{ZnO}$ ganglia phase. Ganglia phase structure with grains of $\mathrm{ZnO}$ : Ag becomes more effective than pure $\mathrm{ZnO}$. The addition of $\mathrm{Ag}$ on $\mathrm{ZnO}$ give good impact to the photocatalytic activity because of the surface of ganglia structure with grains have higher surface area than the surface of pure $\mathrm{ZnO}$ [9]. From the method that has been done by some previous researchers in forming the ganglia phase structure of $\mathrm{ZnO}: \mathrm{Ag}$, in the present study, various concentration of dopant Ag on ZnO using sol-gel method and deposited with thermal spray-coating technique on their microstructure are investigated.

\section{Experiments Procedure}

$\begin{array}{cr}\text { Zinc } & \text { acetate dehydrate } \\ \left(\mathrm{Zn}(\mathrm{COOCH})_{2} .2 \mathrm{H}_{2} \mathrm{O}\right) \text {, } & \text { 2-Propanol } \\ \left(\mathrm{CH}_{3} \mathrm{CH}(\mathrm{OH}) \mathrm{CH}_{3}\right), \text { monoethanolamine (MEA: }\end{array}$
$\left.\mathrm{HOCH}_{2} \mathrm{CH}_{2} \mathrm{NH}_{2}\right)$, and silver nitrate $\left(\mathrm{Ag}\left(\mathrm{NO}_{3}\right)_{2}\right)$ were used for chemical processing. In typical procedure for synthesis of pure $\mathrm{ZnO} 0,3 \mathrm{M}$ zinc acetate dehydrate was dissolve in 2-propanol and MEA 0,3M was added drop wise to zinc acetate solution, then stirred by a magnetic stirrer at a temperature of $70^{\circ} \mathrm{C}$ for 30 minute to get $\mathrm{ZnO}$ sol-gel [10]. Similarly for synthesis of sol-gel $\mathrm{ZnO}: \mathrm{Ag}$ 0,3M zinc acetate solution with amount of silver nitrate with concentration range from 2-8 mol\% was added droped wise to $\mathrm{ZnO}$ solution.

Furthermore to get thin film, sol-gel $\mathrm{ZnO}$ and $\mathrm{ZnO}$ :Ag were deposited by spray thermal coating (shown at Figure1) at the substrate temperature of $250^{\circ} \mathrm{C}$ onto glass substrate for 1 hour. Deposition of $\mathrm{ZnO}$ and $\mathrm{ZnO}$ :Ag film was carried out at atmospheric pressure in a flowing non-sealed system. The post deposition annealing of $\mathrm{ZnO}$ and $\mathrm{ZnO}: \mathrm{Ag}$ film was annealed at the temperature of $400^{\circ} \mathrm{C}$ for 1 hour with the heating and cooling rates of $5 \stackrel{\circ}{\circ} \mathrm{C} /$ minute.

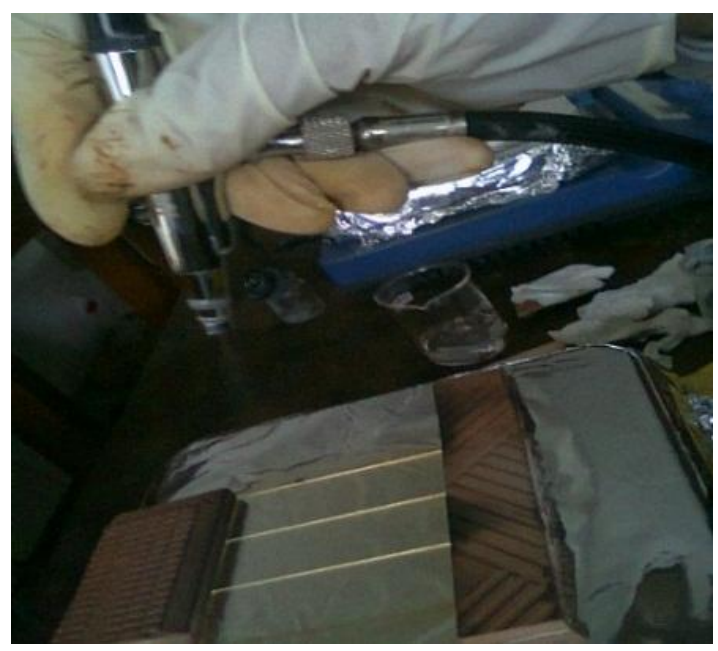

Figure 1. Thermal spray coating technique

The synthesized of $\mathrm{ZnO}$ and $\mathrm{ZnO}: \mathrm{Ag}$ microstructure were observed by Scanning Electron Microscopy (SEM). SEM data obtained was used to analyze the surface of $\mathrm{ZnO}$ and ZnO:Ag. In-house image analysis technique was used to determined the grain size and it's distribution.

\section{Results and Discussion}

Thin film of $\mathrm{ZnO}$ and $\mathrm{ZnO}: \mathrm{Ag}$ with a concentration of $2-8 \mathrm{~mol} \%$ of $\mathrm{ZnO}$ using solgel method has been successfully deposited on a glass substrate measuring $2.54 \mathrm{~cm} \mathrm{x}$ $7.62 \mathrm{~cm} \times 0.1 \mathrm{~cm}$ using thermal spray coating technique. After the coating $\mathrm{ZnO}$ : Ag deposited on a glass substrate, and then characterized using Scanning Electron Microscopy (SEM) to determine the morphology of ZnO layer and $\mathrm{ZnO}$ : Ag.

Figure 2 shows a thin film (a) $\mathrm{ZnO}$, (b) $\mathrm{ZnO}$ : Ag 2 mol\%, (c) ZnO: Ag 4 mol\%, (d) ZnO: Ag 6 mol\%, and (e) ZnO: Ag 8 mol\%. Larger amount of Ag, the thin layer look even darker. The results of the samples showed that more concentration deposited on the substrate, the constituent atoms will be more and more and the gaps between its constituent atoms even 
more tightly, allowing the substrate color is getting darker.

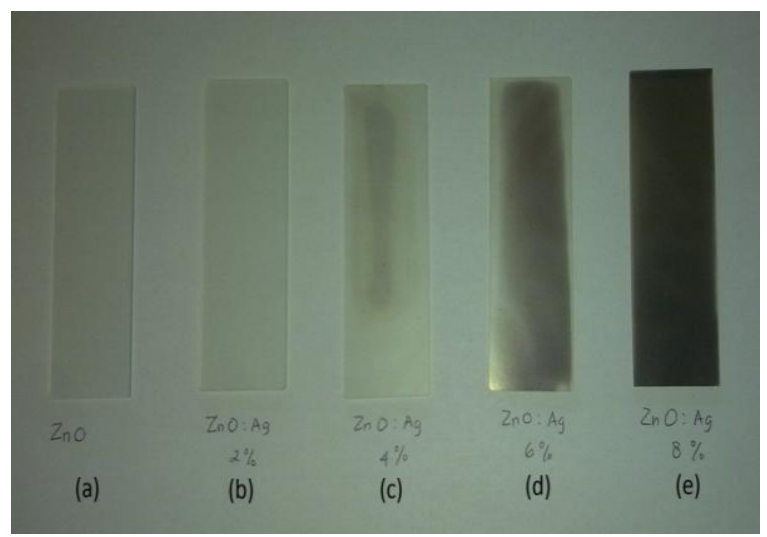

Figure 2. Thin Film of (a) $\mathrm{ZnO}$ and $\mathrm{ZnO}: \mathrm{Ag}$ (b) 2 mol\%, (c) 4 mol\%, (d) 6 mol\% (e) 8 mol\%

Fig. 3 (a) shows the SEM image of the sample $\mathrm{ZnO}$ thin film with a magnification of 10,000 times. Seen in the picture surface morphology of $\mathrm{ZnO}$ thin film with a thermal spray coating method has ganglia-like shape surface [11]. Previous research reports morphology of $\mathrm{ZnO}$ was deposited on a glass substrate by using a dip-coating has similar structure such as ganglia [12] as Figure. 3 (b).

The microstructure of Ag doped $\mathrm{ZnO}$ as $\mathrm{Ag}$ concentration are raised from 2 to $8 \mathrm{~mol} \%$ are shown in Fig. 4. Microstructure of $\mathrm{ZnO}$ : $\mathrm{Ag}$ is the ganglia phase with grains agglutinated to the surface. Grain size was more varied due to the influence of the addition of $\mathrm{Ag}$ dopant on $\mathrm{ZnO}$. It is estimated ganglia is as $\mathrm{ZnO}$ and grains is as Ag.

The grains of Ag have various size for the various concentration. Figure 4 (a) $\mathrm{ZnO}$ : Ag 2\% shows the growth of Ag grains more dominant than the formation of ganglia phase of $\mathrm{ZnO}$. Thin film of $\mathrm{ZnO}$ : Ag 2\% have surface with uniform distribution of the the spherical grains about 76,5 nm is observed. Small amount of $\mathrm{Ag}$ suggest that no chemical reaction between $\mathrm{Ag}$ and $\mathrm{ZnO}$. In previous research the volume of $\mathrm{ZnO}$ unit cell decrease as a small amount of $\mathrm{Ag}$ is added. The size of $\mathrm{Ag}^{+}$ion $(0.122 \mathrm{~nm})$ is larger than $\mathrm{Zn}^{2+}$ ions $(0.088 \mathrm{~nm})$ and therefore level of substitution of $\mathrm{Zn}$ by $\mathrm{Ag}$ is expected to be quite low[6] [8]. In other words, small amount of $\mathrm{Ag}(\leq 4 \mathrm{~mol} \%)$ no chemical reaction so the growth of Ag more dominant than the growth of $\mathrm{ZnO}$.

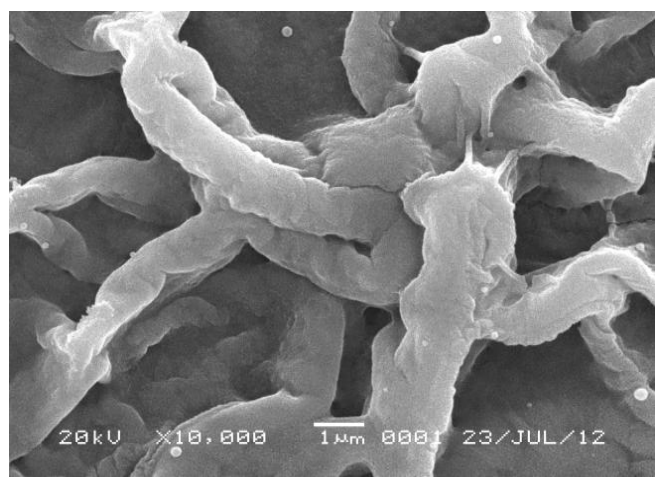

(a)

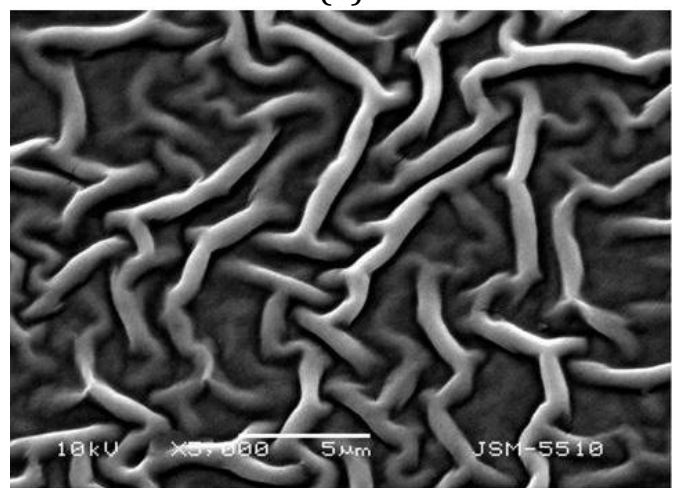

(b)

Figure 3. (a) SEM image of Pure $\mathrm{ZnO}$ using thermal spray coating technique[11] and (b) Pure ZnO using dip-coating technique[12]

Fig. 4 (b), (c) and (d) the addition of $\mathrm{Ag}$ with a concentration of $\geq 4 \mathrm{~mol} \%$ ganglia structure begin to form with the presence of grains. The addition of Ag dopant influence on the formation of $\mathrm{ZnO}$. Increased concentrations of $\mathrm{Ag}$ is added the growth of $\mathrm{ZnO}$ was increase. The addition of $\mathrm{Ag}$ noticeably reduces the scattering of grain sizes [8]. In other words, Ag concentration $\geq 4 \mathrm{~mol} \%$ the growth of $\mathrm{ZnO}$ ganglia are more dominant than $\mathrm{Ag}$ grain growth. Concentration of $6 \mathrm{~mol} \% \mathrm{Ag}$ allegedly began soluble, because $\mathrm{Ag}$ has seen seeping into the $\mathrm{ZnO}$ surface. So it can be said with a concentration of $6 \% \mathrm{Ag}$ acts as a stabilizer in $\mathrm{ZnO}$. But with the addition of $\mathrm{Ag} 8 \mathrm{~mol} \%$ is expected to begin at saturation point, the growth of $\mathrm{ZnO}$ as same as the growth of Ag. shown in Fig. 4 (c) grains of $\mathrm{Ag}$ has seen not seeping but agglutinating to the surface of $\mathrm{ZnO}$. 


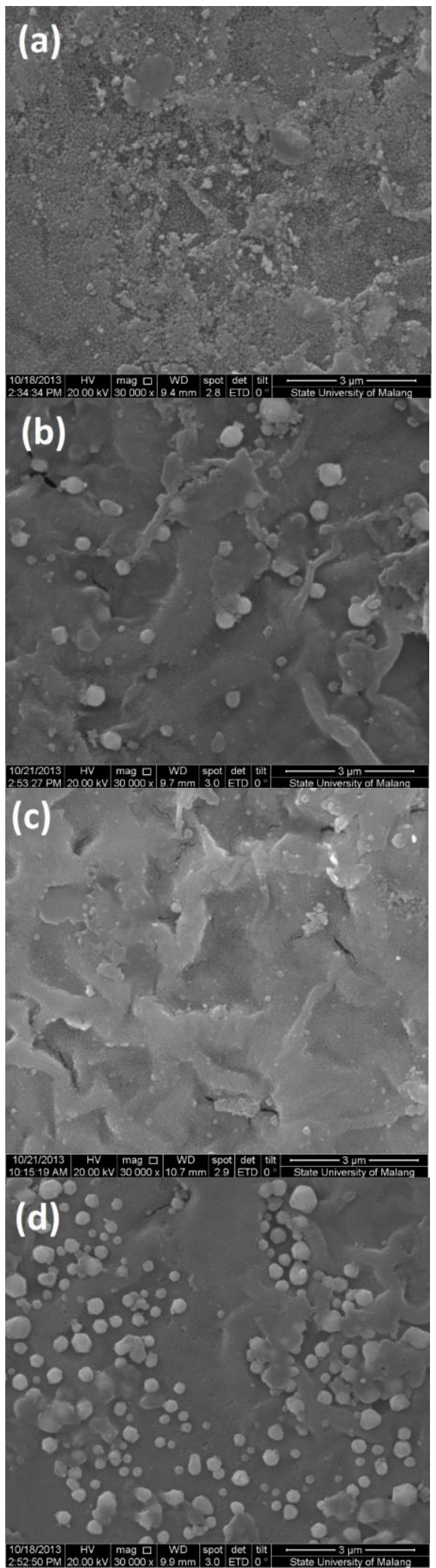

The addition of Ag dopant on $\mathrm{ZnO}$ was also made into variant grain sizes as shown in Table 1. Thin film of $\mathrm{ZnO}: \mathrm{Ag} 4 \%$ indicates that most large grain size in comparison with a thin layer of $\mathrm{ZnO}$ : Ag else that the average diameter of $304.8 \mathrm{~nm}$. In Figure 4 (a) shows a thin layer of Zn0: Ag 2\% have a surface with uniform grain and has a diameter size of the smallest grain that is $76.5 \mathrm{~nm}$.

Table 1. Diameter size of grains $\mathrm{ZnO}$ and $\mathrm{ZnO}: \mathrm{Ag}$

\begin{tabular}{cc}
\hline Sample & diameter size (nm) \\
\hline ZnO & - \\
ZnO:Ag 2\% & 76.5 \\
ZnO:Ag 4\% & 304.8 \\
ZnO:Ag 6\% & 173.4 \\
ZnO:Ag 8\% & 252.5 \\
\hline
\end{tabular}

\section{Conclusion}

$\mathrm{ZnO}$ and $\mathrm{ZnO}$ : Ag with a concentration of 2$8 \mathrm{~mol} \%$ of $\mathrm{ZnO}$ using sol-gel method has been successfully deposited on a glass substrate using thermal spray coating technique. Microstructure of $\mathrm{ZnO}$ : Ag is ganglia phase act as $\mathrm{ZnO}$ and grains act as $\mathrm{Ag}$ was covered the surface. The addition concentration of $\mathrm{Ag}$ dopant on $\mathrm{ZnO}$ promotes the growth of ganglia phase and grain size. The surface of $\mathrm{ZnO}: \mathrm{Ag} \leq 4$ mol\% the growth grain $\mathrm{Ag}$ is more dominant than the growth of $\mathrm{ZnO}$ due to the low concentration of Ag suggest that no chemical reaction between $\mathrm{Ag}$ and $\mathrm{ZnO}$. However, when the dopant Ag with a concentration of 4-8 mol\% ganglia structure begin to form with the presence of grains. By increasing concentration of dopant $\mathrm{Ag}$ on $\mathrm{ZnO}$ noticeably reduces the scattering of grain sizes. Ag Dopant $8 \mathrm{~mol} \%$ is expected to begin at saturation point, the growth of $\mathrm{ZnO}$ as same as the growth of Ag. Obtained dopant Ag 4\% have a diameter the size of the largest grain in the amount of 304.8 $\mathrm{nm}$.

Figure 4. SEM Image of thin film $\mathrm{ZnO}: \mathrm{Ag}$ (a) $2 \mathrm{~mol} \%$, (b) $4 \mathrm{~mol} \%$, (c) $6 \mathrm{~mol} \%$, (d) $8 \mathrm{~mol} \%$ 


\section{Acknowledgment}

The authors wish to thank DPPM DIKTI for supporting this work.

\section{References}

[1] K. B. Dermenci, B. Ebin, and S. Gürmen, "Production of Spherical Ag / $\mathrm{ZnO}$ Nanocomposite Particles for Photocatalytic Applications," pp. 570572, 2012.

[2] X. Yin, W. Que, D. Fei, F. Shen, and Q. Guo, "Ag nanoparticle/ZnO nanorods nanocomposites derived by a seedmediated method and their photocatalytic properties," J. Alloys Compd., vol. 524, pp. 13-21, 2012.

[3] Z. G. Jia, K. K. Peng, Y. H. Li, and R. S. Zhu, "Preparation and photocatalytic performance of porous $\mathrm{ZnO}$ microrods loaded with Ag," Trans. Nonferrous Met. Soc. China (English Ed., vol. 22, no. 4, pp. 873-878, 2012.

[4] R. Chauhan, A. Kumar, R. P. Chaudhary, and T. Education, "Synthesis and characterization of silver doped $\mathrm{ZnO}$ nanoparticles," Arch. Appl. Sci. Res., vol. 2, no. 5, pp. 378-385, 2010.

[5] C. Karunakaran, V. Rajeswari, and P. Gomathisankar, "Optical, electrical, photocatalytic, and bactericidal properties of microwave synthesized nanocrystalline Ag-ZnO and $\mathrm{ZnO}$," Solid State Sci., vol. 13, no. 5, pp. 923-928, 2011.

[6] P. Amornpitoksuk, S. Suwanboon, S. Sangkanu, A. Sukhoom, N. Muensit, and J. Baltrusaitis, "Synthesis, characterization, photocatalytic and antibacterial activities of Ag-doped $\mathrm{ZnO}$ powders modified with a diblock copolymer," Powder Technol., vol. 219, pp. 158-164, 2012.
[7] A. Shah, E. Manikandan, M. Ahmed, and V. Ganesan, "Enhanced Bioactivity of $\mathrm{Ag} / \mathrm{ZnO}$ Nanorods-A Comparative Antibacterial Study (Sbds)," J. Nanomed. Nanotechnol., vol. 4 (3), no. 3, pp. 1-6, 2013.

[8] S.-T. Kuo, W.-H. Tuan, J. Shieh, and S.-F. Wang, "Effect of $\mathrm{Ag}$ on the micro structure and electrical properties of ZnO," J. Eur. Ceram. Soc., vol. 27, no. 16, pp. 4521-4527, 2007.

[9] D. Lapisan, T. Zno, A. Dan, S. Rully, and H. Sutanto, "Aplikasinya Untuk Degradasi Polutan," vol. 17, no. 3, pp. 85-90, 2014.

[10] D. H. S. Sistesya, "SIFAT OPTIS LAPISAN Zno:Ag YANG DIDEPOSISI DI ATAS SUBSTRAT KACA MENGGUNAKAN METODE CHEMICAL SOLUTION DEPOSITION (CSD) DAN APLIKASINYA PADA DEGRADASI ZAT WARNA METHYLENE BLUE," Youngster Phys. J., vol. 1, no. 4, 2013.

[11] M. Pusvitasari, "Deposisi Lapisan Tipis Zinc Oxide (ZnO) di Atas Substrat Kaca dengan Metode Sol-Gel untuk Aplikasi Degadrasi Warna," Youngster Phys. J., vol. 1, no. 1, 2012.

[12] “6. N. Kaneva_149-156.pdf.”. 